Jurnal BASTRA (Bahasa dan Sastra) : http://ojs.uho.ac.id/index.php/BASTRA

\title{
MORALITAS DALAM NOVEL BIDADARI BERMATA BENING KARYA HABIBURRAHMAN EL SHIRAZY
}

\author{
OLEH \\ Hajarwati Beladin ${ }^{1}$, La Ode Sahidin ${ }^{2}$ dan Irianto Ibrahim ${ }^{3}$ \\ ${ }^{1}$ Alumni Jurusan Pend. Bahasa dan Sastra Indonesia, ${ }^{2,3}$ Dosen Jurusan Pendidikan \\ Bahasa dan Sastra Indonesia, Fakultas Keguruan dan Ilmu Pendidikan \\ Universitas Halu Oleo
}

\begin{abstract}
ABSTRAK
Tujuan dalam penelitian ini adalah menemukan moralitas Islam yang terdapat dalam novel Bidadari Bermata Bening karya Habiburrahman El Shirazy. Metode penelitian yang digunakan dalam penelitian ini adalah metode deskriptif kualitatif. Jenis penelitian ini adalah kualitatif yang tidak menggunakan prinsip statistik, melainkan berpedoman pada teori-teori sastra yang berkaitan dengan penelitian. Manfaat yang dapat diperoleh dari penelitian ini, yaitu menambah pengetahuan bagi penulis maupun pembaca. Data yang digunakan dalam penelitian ini adalah data tertulis yaitu berupa teks novel yang berhubungan dengan moralitas Islam dalam novel Bidadari Bermata Bening karya Habiburrahman El Shirazy. Sumber data dalam penelitian ini adalah novel Bidadari Bermata Bening karya Habiburrahman El Shirazy yang diterbitkan oleh Republika cetakan kelima Desember 2017, dengan jumlah 337 halaman. Teknik yang digunakan untuk mengumpulkan data dalam penelitian ini adalah teknik baca-catat. Teknik analisis data menggunakan pendekatan moral dengan melihat isi dan tujuan yang tersirat di dalam karya sastra itu sendiri dengan menginterpretasikan tentang moralitas Islam. Berdasarkan pembahasan hasil penelitian, dapat disimpulkan bahwa moralitas Islam dalam artian yaitu akhlak yang terdapat dalam novel Bidadari Bermata Bening karya Habiburrahman El Shirazy mencakup empat akhlak, yaitu yang pertama akhlak terhadap Allah Swt. yaitu Syukur, Berdoa, Taat beribadah (shalat) dan Ridho. Yang kedua adalah akhlak terhadap Rasulullah yaitu: Mengucapkan shalawat dan Taat pada Sunnah Rasulullah. Yang ketiga adalah akhlak terhadap diri sendiri yaitu Sabar, Amanah, Bekerja keras, Rendah hati, Suka menolong dan jujur. Dan yang ke-empat adalah akhlak terhadap masyarakat yaitu: menyayangi anak yatim dan menjenguk orang sakit.
\end{abstract}

Kata Kunci: moralitas islam, novel 


\section{PENDAHULUAN}

\subsection{Latar Belakang}

Bangsa Indonesia dikenal dengan bangsa yang berbudi luhur tinggi, ramah, bersahaja dan menjunjung tinggi tata krama dalam pergaulan sebagaimana anak bersikap pada orang tua, orang tua kepada yang lebih muda, maupun pada hubungan antar teman. Namun, kondisi masyarakat dewasa ini kurang mempedulikan moralitas yang ada. Kenyataan itu didasarkan dengan merosotnya moralitas Islam yang dimiliki masyarakat Indonesia terutama dari kalangan muda pada zaman sekarang ini.

Perkembangan teknologi yang sangat pesat di era globalisasi ini merupakan salah satu penyebab merosotnya moralitas Islam masyarakat Indonesia. Banyak masyarakat Indonesia yang salah dalam menyikapi perkembangan teknologi yang ada. Perilaku masyarakat, terutama generasi muda sekarang ini semakin memperihatinkan, para generasi muda lebih bebas mengekspresikan diri. Bukan hanya itu, saat ini para generasi muda juga sangat minim sopan santun terhadap orang yang lebih tua, terhadap tenaga pendidik dan terhadap masyarakat sekitar.

Para generasi muda yang notabene akan menjadi penerus bangsa, seharusnya bisa memiliki moralitas yang baik. Moralitas memiliki kedudukan yang sangat penting karena kehidupan manusia diatur oleh adat istiadat, norma-norma, aturan serta hukum yang ada dalam masyarakat yang telah menjadi kesepakatan bersama. Beradab atau tidaknya suatu bangsa dapat dilihat dari perilaku masyarakatnya, terutama aspek moralitasnya atau yang sering disebut akhlak. Akhlak adalah cerminan hidup bagi penegak bangsa dan menjadi tolak ukur kepribadian bangsa itu sendiri.

Moralitas bangsa Indonesia dahulu sangat kental sesuai adat istiadat dan budaya bangsa. Pada masa orang tua kita dulu, mereka diajari bagaimana bersikap dan bertutur kata. Seperti kebiasaan mencium tangan kepada orang yang lebih tua umurnya dan berjalan agak menundukkan badan ketika melewati diantara orang tua yang sedang bercerita. Hal seperti ini sering diajarkan oleh orang tua kepada anaknya. Namun, pada masa sekarang ini moralitas remaja sangat berbeda jauh dibandingkan moralitas pada masa orang tua kita dulu. Pada masa sekarang, remaja banyak yang kurang memperhatikan sopan santun dan moralitas dalam bersikap, seperti suka melawan orang tua, melawan guru di sekolah, senang tawuran dan pergaulan bebas. Hal ini terjadi sebab kurangnya pengetahuan remaja tentang moralitas dalam Islam.

Islam merupakan agama yang banyak mengajarkan tentang nilai moralitas. Agama Islam memandang nilai moralitas (akhlak) merupakan salah satu ajaran yang terpenting dalam jiwa setiap manusia. Pentingnya moralitas (akhlak) dalam Islam dapat dilihat dari salah satu tujuan diutusnya Nabi Muhammad adalah untuk menyempurnakan akhlak yang mulia. Nabi Muhammad SAW bersabda:

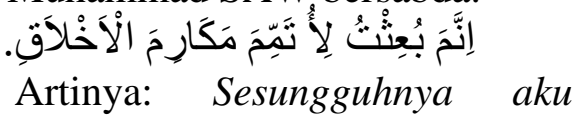
diutus hanya untuk menyempurnakan kemuliaan akhlak.

Kurangnya pengetahuan remaja tentang moralitas Islam dapat dicegah dengan adanya penanaman pemahaman tentang moralitas Islam. Penanaman moralitas Islam 
sebenarnya dapat ditanamkan tidak hanya melalui pendidikan di sekolah atau madrasah semata. Namun, dapat disampaikan melalui bahan bacaan yang berkualitas. Karya sastra merupakan salah satu solusi yang dapat digunakan untuk menanamkan nilai moralitas Islam guna mencegah bertambah banyaknya remaja yang kurang dalam memahami moralitas Islam.

Melalui karya sastra, pembaca akan dengan sangat mudah menyerap moralitas Islam yang terkandung di dalamnya. Pembaca karya sastra dapat menyelami moralitas Islam yang dimiliki tiap-tiap tokoh, dan bagaimana dunia merespon tindakan yang dilakukan tokoh dengan lebih nyata. Unsur imajinasi yang tertuang dalam karya sastra dapat membimbing pembaca dalam berpikir, bertindak dan berkarya sesuai dengan nilai-nilai yang ada.

Salah satu bentuk karya sastra yang paling popular adalah novel. Novel yang mengangkat masalah tentang moralitas Islam yang menjadi objek penelitian peneliti adalah novel Bidadari Bermata Bening karya Habiburrahman El Shirazy. Habiburrahman El Shirazy adalah sastrawan dan cendekiawan Indonesia bereputasi Internasional. Ia adalah sastrawan Asia Tenggara pertama yang mendapat penghargaan dari The Istanbul Foundation for Sciences and Culture, Turki. Sebelum menerbitkan novel Bidadari Bermata Bening, Habiburrahman El Shirazy telah lebih dulu menerbitkan novel Ayat-ayat Cinta yang menjadi best seller dan bahkan novel Ayat-ayat Cinta telah berhasil menembus layar bioskop Indonesia. Adapun beberapa karya populer dari Habiburrahman El Shirazy adalah novel Ketika Cinta
Berbuah Surga, Pudarnya Pesona Cleopatra, Di atas Sajadah Cinta, Ketika Cinta Bertasbih 1, Ketika Cinta Bertasbih 2, Dalam Mihrab Cinta, Bumi Cinta, The Romans, Cinta Suci Zahrana, Api Tauhid, Bulan Madu di Yerussalem, dan Dari Sujud ke Sujud.

Novel Bidadari Bermata Bening diterbitkan di Jakarta oleh Republika Penerbit, cetakan kelima pada Desember tahun 2017 dengan jumlah halaman sebanyak 337 halaman. Novel ini mendeskripsikan dunia pesantren dan orang-orang pesantren dengan apik. Khazanah dan nilai-nilai moral pesantren pun disampaikan dengan bahasa sastra yang indah. Lebih dari itu, novel ini memotivasi para santri dan generasi muda pada umumnya untuk meraih kesuksesan dengan bekerja keras, ulet, rendah hati, dan menebar kebaikan secara universal.

Novel Bidadari Bermata Bening mengisahkan tentang seorang gadis cantik yang bernama Ayna Mardeya yang akrab disapa Ayna. Ayna adalah seorang santriwati yang mondok di pesantren Kanzul Ulum. Ayna bukanlah santri biasa, ia adalah santri yang juga merangkap sebagai khadimah (pembantu perempuan) yang membantu $\mathrm{Bu}$ Nyai Fauziyah selaku Pembina di pesantren tersebut. Wajah cantik dan budi yang baik tak serta merta membuat Ayna disenangi banyak orang, Neneng misalnya, Neneng yang juga menjadi santri di pesantren itu selalu bersikap tidak baik terhadap Ayna. Ayna yang memiliki prestasi baik di pesantren itu dan meraih nilai UN (Ujian Nasional) terbaik, membuat Neneng geram. Saking geramnya Neneng sampaisampai memfitnah Ayna dengan tuduhan bahwa Ayna adalah anak hasil zina dari seorang TKW (Tenaga Kerja 
Wanita) yang serong dengan majikannya.

Moralitas Islam yang dimaksud dalam penelitian ini adalah berfokus pada akhlak. Sebab moralitas dalam Islam setara maknanya dengan akhlak. Moralitas dan akhlak memiliki implementasi yang sama yaitu samasama mengacu kepada manusia baik dari aspek perilaku ataupun pemikiran khususnya pada penentuan hukum atau nilai dari suatu perbuatan yang dilakukan manusia untuk ditentukan baik buruknya. Moralitas dan akhlak sama-sama menghendaki terciptanya keadaan masyarakat yang baik, teratur, aman, damai dan sejahtera. Maka penelitian ini berfokus pada macammacam akhlak yang terdapat dalam novel ini yaitu akhlak terhadap Allah Swt., akhlak terhadap Rasulullah Saw, akhlak terhadap diri sendiri dan akhlak terhadap masyarakat.

Melihat banyaknya moralitas Islam dalam artian akhlak yang terdapat dalam Novel Bidadari Bermata Bening, maka peneliti tertarik untuk meneliti novel ini berdasarkan tinjauan moral dengan mengangkat judul penelitian "Moralitas Islam dalam Novel Bidadari Bermata Bening karya Habiburrahman El Shirazy”.

\subsection{Rumusan Masalah}

Berdasarkan uraian latar belakang tersebut, maka masalah dalam penelitian ini adalah moralitas Islam apa sajakah yang terdapat dalam novel Bidadari Bermata Bening karya Habiburrahman El Shirazy?

\subsection{Tujuan Penelitian}

Untuk menemukan moralitas Islam apa saja yang terdapat dalam novel Bidadari Bermata Bening karya Habiburrahman El Shirazy.

\subsection{Manfaat Penelitian}

1. Pembaca sebagai penikmat sastra akan lebih memahami nilai moral yang terdapat dalam novel Bidadari Bermata Bening karya Habiburrahman El Shirazy.

2. Sebagai motivasi atau masukan terhadap guru dan siswa dalam menganalisis nilai moral yang terdapat dalam sebuah karya sastra khususnya novel.

3. Sebagai bahan penelitian lanjutan dalam melaksanakan penelitian yang relevan dengan penelitian ini.

\section{KAJIAN PUSTAKA \\ 2.1 Pengertian Moralitas}

Moralitas secara lughowi (makna bahasa) berasal dari kata mos bahasa Latin (jamak, mores) yang berarti kebiasaan, adat istiadat. Moral, diambil dari bahasa Latin mos (jamak, mores) yang berarti kebiasaan, adat. Kata 'bermoral' mengacu pada bagaimana suatu masyarakat yang berbudaya berperilaku. Dan kata moralitas juga merupakan kata sifat latin moralis, mempunyai arti sama dengan moral hanya nada lebih abstrak. Kata moral dan moralitas memiliki arti yang sama, maka dalam pengertiannya lebih ditekankan pada penggunaan moralitas, karena sifatnya yang abstrak. Moralitas adalah sifat moral atau keseluruhan asas dan nilai yang berkenaan dengan baik buruk. Senada dengan pengertian tersebut, W.Poespoprodjo mendefinisikan moralitas sebagai kualitas dalam perbuatan manusia yang menunjukkan bahwa perbuatan itu benar atau salah, baik atau buruk. Moralitas mencakup baik buruknya manusia.

Moralitas adalah sistem nilai tentang bagaimana kita harus hidup secara baik sebagai manusia, sistem nilai ini 
terkandung dalam ajaran berbentuk petuah-petuah, nasihat, wejangan, peraturan, perintah dan semacamnya yang diwariskan secara turun-temurun melalui agama atau kebudayaan tertentu tentang bagaimana manusia harus hidup secara baik.

Menurut Durkeim (1990: 10) moralitas merupakan konsistensi, keteraturan tingkah: apa yang akan menjadi moral hari ini akan menjadi moral esok hari. Moralitas juga meliputi pengertian wewenang: kita dipaksa untuk bertindak dengan caracara tertentu kita merasakan perlawanan terhadap impuls-impuls (dorongan hati) yang tidak masuk akal.

Berdasarkan beberapa pendapat di atas dapat disimpulkan bahwa moralitas adalah sifat moral atau keseluruhan asas dan nilai yang berkenaan dengan tingkah laku baik dan buruk yang dilakukan oleh seseorang.

\subsection{Pengertian Moralitas Islam}

Moral secara etimologi berasal dari kata mos dalam bahasa Latin, bentuk jamaknya mores yang artinya adalah tata cara atau adat-istiadat. Dalam kamus Besar Bahasa Indonesia (2002: 756), moral diartikan sebagai ajaran tentang baik buruk yang diterima umum mengenai perbuatan, sikap, kewajiban, dan sebagainya; akhlak, budi pekerti atau susila. Kemudian kata moral mendapat imbuhan itas menjadi moralitas yang bermakna sifat. Sehingga moralitas adalah sifat moral atau keseluruhan asas dan nilai yang berkenaan dengan baik dan buruk (Bertens, 2002: 7).

Moralitas memiliki implementasi yang sama dengan akhlak, yaitu samasama untuk menentukan baik dan buruk hanya saja tolak ukurnya yang berbeda. Moralitas diukur berdasarkan kebiasaan yang berlaku di masyarakat, sedangkan akhlak diukur berdasarkan Alquran dan Alhadis. Dalam bahasa Indonesia, moralitas dan akhlak maksudnya sama dengan budi pekerti atau kesusilaan. Kalau membawanya dalam perspektif Islam, kita tidak dapat menemukan moral, yang kita dapatkan adalah istilah akhlak. Kata akhlak berasal dari kata khalaqa (bahasa Arab) yang berarti perangai, tabi'at dan adat istiadat. Meskipun akhlak berasal dari bahasa Arab, tetapi kata akhlak tidak terdapat di dalam AlQuran. Satu-satunya kata yang ditemukan semakna akhlak dalam AlQuran adalah bentuk tunggal, yaitu huluk yang tercantum dalam Q.S AlQalam ayat 4:

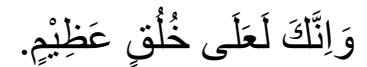

Artinya: Dan sesungguhnya engkau benar-benar, berbudi pekerti yang luhur.

Dalam Al-Quran pun Allah
memerintahkan umatnya untuk menghiasi dirinya dengan perbuatanperbuatan yang baik dan jangan mengotori dirinya dengan perbuatanperbuatan yang tercela, seperti firman Allah dalam Q.S Asy-Syams [91] ayat 9-10:

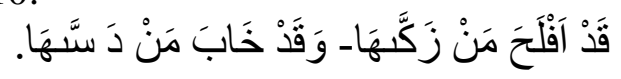
Artinya: Sungguh beruntung orang yang menyucikannya (jiwa itu), dan sungguh rugi orang yang mengotorinya.

dan menghargai, bekerja keras, menepati janji, tahu balas budi, baik budi pekerti, rendah hati, dan hati-hati dalam bertindak, Simongkir (dalam Mada, 2017: 3).

\subsection{Pengertian Akhlak}

\begin{tabular}{llr}
\multicolumn{2}{c}{ Al-Ghazali } & \multicolumn{2}{c}{ mendefinisikan } \\
akhlak dalam & kitabnya Ihya \\
Ulumuddin adalah akhlak sebagai
\end{tabular}


suatu perangai (watak/ tabi'at) yang menetap dalam jiwa seseorang dan merupakan sumber timbulnya perbuatan-perbuatan tertentu dari dirinya secara mudah dan ringan, tanpa dipikirkan atau direncanakan sebelumnya. Hal ini juga yang menjadi salah satu tugas rasulullah Muhammad SAW, sebagaimana dinyatakan dalam hadits dibawah ini:

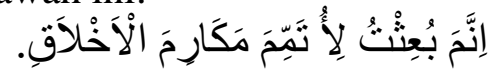

Artinya: Sesungguhnya aku diutus hanya untuk menyempurnakan kemuliaan akhlak.

Pengertian akhlak hampir sama dengan yang dikatakan oleh Ibn Maskawih. Menurut Ibn Maskawih dalam kitabnya Tahzibul Akhlak, akhlak adalah suatu keadaan jiwa yang menyebabkan timbulnya perbuatan tanpa melalui pertimbangan dan dipikirkan secara mendalam. Apabila dari perangai tersebut timbul perbuatan baik, maka perbuatan demikian disebut akhlak baik. Demikian sebaliknya, jika perbuatan yang ditimbulkannya perbuatan buruk, maka disebut akhlak jelek.

Dalam khazanah pembendaharaan bahasa Indonesia kata yang setara maknanya dengan akhlak adalah moral. Kata-kata ini sering disejajarkan dengan budi pekerti, tata susila, tata krama atau sopan santun (Faisal Ismail, 1998: 178).

Pendapat lain yang menguatkan persamaan arti moral dan akhlak adalah pendapat Muslim Nurdin. Muslim Nurdin (1993: 205) mengatakan bahwa akhlak adalah seperangkat nilai yang dijadikan tolak ukur untuk menentukan baik buruknya suatu perbuatan, atau suatu sistem nilai yang mengatur pola sikap dan tindakan manusia. Dengan demikian, dapat dikatakan bahwa tidak ada perbedaan yang mendasar antara moral dan akhlak. Keduanya bisa dikatakan sama, kendatipun tidak dipungkiri ada sebagian pemikir yang tidak sependapat dengan mempersamakan kedua istilah tersebut. Menurut AlFarabi dalam (Amril, 2007: 6) sesungguhnya akhlak itu merupakan upaya menumbuhkembangkan akhlak potensial baik yang ada dalam diri setiap manusia dengan jalan membiasakan lahirnya perilakuperilaku yang terpuji dan membangun situasi dan kondisi yang kondusif untuk tumbuh dan berkembangnya perilaku yang terpuji dalam diri seseorang. Menurut Azra (2005: 130) akhlak adalah keadaan melekat pada jiwa manusia yang darinya lahir suatu perbuatan dengan mudah, tanpa melalui proses pemikiran, pertimbangan, atau penelitian.

Ma'ruf dalam (Mustofa, 1997: 14) mendefinisikan akhlak sebagai kehendak jiwa manusia yang menimbulkan perbuatan dengan mudah karena kebiasaan, tanpa memerlukan pertimbangan pikiran terlebih dahulu.

Dari beberapa pendapat di atas dapat disimpulkan bahwa akhlak adalah sifat yang sudah tertanam kuat dalam batin seseorang serta telah menjadi kebiasaan.

\subsection{Macam-Macam Akhlak}

\subsubsection{Akhlak terhadap Allah Swt.}

Menurut Kahar Masyhur Akhlak terhadap Allah dapat diartikan sebagai sikap dan perbuatan yang seharusnya dilakukan oleh manusia sebagai makhluk kepada Tuhan sebagai khalik. Titik tolak akhlak terhadap Allah adalah pengakuan dan kesadaran bahwa tiada Tuhan melainkan Allah. Sekurang-kurangnya ada empat alasan mengapa manusia perlu berakhlak kepada Allah. 
Pertama, karena Allah yang telah menciptakan manusia. Kedua, karena Allah yang telah memberikan perlengkapan panca indera, akal pikiran dan hati sanubari, disamping anggota badan yang kokoh dan sempurna kepada manusia. Ketiga, karena Allah yang telah menyediakan berbagai bahan dan sarana yang diperlukan bagi kelangsungan hidup manusia. Keempat, Allah yang telah memuliakan manusia dengan diberikannya kemampuan untuk menguasai daratan, lautan dan udara. Akhlak terhadap Allah meliputi: syukur, berdoa, beribadah (shalat) dan ridho.

\subsubsection{Akhlak terhadap Sunnah Rasulullah SAW}

Akhlak terhadap sunnah Rasulullah dapat diartikan sebagai suatu sikap yang harus dilakukan oleh manusia kepada Rasulullah sebagai rasa terima kasih atas perjuangannya membawa umat manusia ke jalan yang benar. Akhlak terhadap sunnah Rasulullah meliputi: mengucapkan shalawat dan taat pada sunnah Rasulullah Saw.

\subsubsection{Akhlak terhadap Diri Sendiri}

Akhlak terhadap diri sendiri dapat diartikan sebagai sikap pemenuhan semua urusan kita sepenuhnya kepada-Nya, baik yang menyangkut jasmani maupun rohani. Akhlak terhadap diri sendiri meliputi: sabar, amanah, bekerja keras, rendah hati, suka menolong dan jujur.

\subsubsection{Akhlak terhadap Masyarakat}

Akhlak terhadap masyarakat adalah sifat yang tertanam dalam jiwa manusia yang dilakukan secara spontan tanpa pertimbangan terlebih dahulu dalam lingkungan atau kehidupan. Akhlak terhadap masyarakat meliputi: menyayangi anak yatim dan menjenguk orang sakit.

\subsection{Pengertian Sastra}

Menurut Padi (2013: 1) sastra (Sansekerta/Shastra) merupakan kata serapan dari bahasa Sansekerta, sastra yang berarti "teks yang mengandung instruksi" atau "pedoman", dari kata dasar sas yang berarti "instruksi" atau "ajaran". Dalam bahasa Indonesia kata ini biasa digunakan untuk merujuk kepada "kesusastraan" atau sebuah jenis tulisan yang memiliki arti atau keindahan tertentu.

Teeuw (dalam Sutana, 2015: 3) menyatakan bahwa karya sastra tidak dapat dipisahkan dari fakta budaya dan sosial budayanya. Karena alasan tersebut disamping pendekatan intrinsik (mikro sastra), pendekatan ekstrinsik dipakai juga untuk mengungkapkan hubungan antara karya sastra dan lingkungannya.

Wellek (2016: 294-295) mengatakan bahwa kita tidak bisa menolak untuk menghargai karya sastra, hanya karena kita tidak percaya bahwa sastra memiliki suatu "nilai estetis" puncak yang tidak bisa di kurangi. Berdasarkan suatu sistem nilai yang "nyata" dan final, kita tidak bisa membagi atau memberi karya seni tertentu, atau seni pada umumnya, "sepotong" atau sejumput nilai. Seperti sejumlah filsuf, kita dapat menganggap seni sebagai suatu bentuk pengetahuan yang primitif dan lebih rendah. Atau, kita dapat mengukur sastra berdasarkan kemampuannya untuk melakukan tindakan. Bisa juga kita melihat nilai sastra pada cakupannya yang luas, yang meliputi apa saja.

Berdasarkan dari beberapa pendapat tersebut dapat disimpulkan bahwa sastra merupakan suatu karya 
seni yang indah dan menggunakan bahasa sebagai media penyampainya.

\subsection{Pengertian Novel}

Novel berasal dari bahasa Italia novella yang berarti sebuah barang baru yang kecil, dan kemudian diartikan sebagai 'cerita pendek dalam bentuk prosa'. Dewasa ini istilah novella dan novelle mengandung pengertian yang sama dengan istilah Indonesia 'novelet'( Inggris novelette), yang berarti sebuah karya prosa fiksi yang panjangnya cukupan, tidak terlalu panjang, namun juga tidak terlalu pendek. (Nurgiyantoro, 2015: 12).

Kosasih (2012: 60) novel
adalah karya imajinatif yang mengisahkan sisi utuh atas problematika kehidupan seseorang atau beberapa orang tokoh. Novel adalah sebuah karya fiksi prosa yang tertulis dan naratif. Biasanya dalam bentuk cerita. Penulis novel disebut novelis. Kata novel berasal dari Italia, "novella" yang berarti "sebuah kisah, sepotong berita". (Redaksi PM, 2012: 42).

Menurut Padi (2013: 45) novel adalah fiksi prosa yang tertulis dan naratif. Biasanya dalam bentuk cerita. Penulis novel disebut novelis. Novel dalam bahasa Indonesia dibedakan dari roman. Sebuah roman alur ceritanya lebih kompleks dan jumlah pemeran atau tokoh cerita juga lebih banyak.

Semi (dalam Wicaksono, 2014: 115) menyatakan bahwa novel mengungkapkan suatu konsentrasi kehidupan pada suatu saat tegang, dan pemusatan kehidupan yang tegas. Novel merupakan karya fiksi yang mengungkap aspek kemanusiaan yang lebih mendalam dan disajikan dengan halus.

Berdasarkan beberapa pendapat yang dikemukakan tersebut, dapat disimpulkan bahwa novel adalah ragam karya sastra berbentuk prosa yang berisi tentang kehidupan manusia, melalui beberapa aspek kehidupan sehingga mampu membawa pembaca kearah perenungan mengenai isi cerita serta dapat memberi kesan moral tersendiri bagi pembaca.

\subsection{Pengertian Pendekatan Moral}

Pendekatan moral bertolak dari asumsi dasar bahwa salah satu tujuankehadiran sastra di tengahtengah masyarakat pembaca adalah berupaya untuk meningkatkan harkat dan martabat manusia sebagai makhluk berbudaya, berpikir dan berketuhanan. Memang karya sastra tidak safah, gagasan, tema dan pesanpesan tertentu. Dengan pendekatan moral ini peneliti hendak melihat sejauh mana sebuah karya sastra itu memiliki moral. Moral dalam pengertian filsafat merupakan suatu konsep yang telah dirumuskan oleh sebuah masyarakat bagi menentukan kebaikan atau keburukan. Karena itu, moral merupakan suatu norma tentang kehidupan yang telah diberikan kedudukan istimewah dalam kegiatan atau kehidupan sebuah masyarakat. (Semi, 1990: 71).

Semi (1990: 71) mengemukakan pendekatan moral mempunyai konsepsi dan kriteria sebagai berikut:

1. Sebuah karya sastra yang benilai tinggiadalah karya sastra yang mengandung moral yang tinggi, yang dapat mengangkat harkat umat manusia. Dalam hal ini karya sastra diciptakan oleh seorang penulis tidak semata-mata mengandalkan bakat dan kemahiran berekspresi, tetapi lebih dari itu, seorang penulis melahirkan karya sastra karena ia juga ingin memiliki visi, aspirasi, itikad baik, dan perjuangan, sehingga karya sastra yang 
dihasilkannya memiliki nilai tinggi. Karya sastra yang hanya mementingkan nilai seni memperhatikan moral dinilai sebagai karya yang tidak bermutu.

2. Dalam memberikan ukuran baik dan buruk lebih menitikberatkan kepada masalah isi seperti tema, pemikiran, falsafah, dan pesanpesan dibandingkan dengan masalah bentuk. Masalah bentuk dalam pendekatan ini memang agak diabaikan, karena pandangan bahwa mutu karya sastra bukan ditentukan oleh bagaimana gagasan disajikan tetapi bagaimana kemampuan, krya tersebut, memotivasi masyarakat, ke arah kehidupan yang lebih baik.

3. Masalah didaktis, yakni pendidikan dan pengajaran, yang dapat mengantarkan pembaca kepada suatu arah tertentu. Oleh sebab itu karya sastra yang baik adalah karya sastra yang memperlihatkan tokohtokoh yang memiliki kebijakan da kearifan sehingga pembaca dapat mengambilnya sebagai teladan.

4. Pendekatan moral menghendaki sastra menjadi medium perekaman keperluan zaman, yang memiliki semangat menggerakkan masyarakat ke arah budi pekerti yang terpuji. Karya sastra dalam hal ini dinilai sebagai guru yang dapat dijadikan penutun.

\section{METODE PENELITIAN DAN TEKNIK PENELITIAN}

\subsection{Metode dan Jenis Penelitian}

Metode yang digunakan dalam penelitian ini adalah metode deskriptif kualitatif. Dikatakan deskriptif karena peneliti menemukan data yang akan di analisis berupa moralitas Islam dalam novel Bidadari Bermata Bening karya Habiburrahman El Shirazy. Dikatakan kualitatif karena dalam menjelaskan konsep-konsep yang berkaitan satu sama lain yang dilakukan dengan menggunakan kata-kata atau kalimat, bukan menggunakan angka-angka statistik.

Jenis penelitian yang digunakan dalam penelitian ini adalah penelitian kualitatif yang tidak menggunakan prinsip statistik, melainkan berpedoman pada teori-teori sastra yang berkaitan dengan penelitian.

\subsection{Data dan Sumber Data}

Data dalam penelitian ini adalah data tertulis berupa teks novel yang berhubungan dengan moralitas Islam yang terdapat dalam novel Bidadari Bermata Bening karya Habiburrahman El Shirazy.

Sumber data dalam dalam penelitian ini adalah novel Bidadari Bermata Bening karya Habiburrahman El Shirazy yang diterbitkan oleh Republika cetakan kelima Desember 2017, dengan jumlah 337 halaman.

\subsection{Teknik Pengumpulan Data}

Teknik pengumpulan data yang digunakan dalam penelitian ini adalah teknik baca-catat yang dilaksanakan dengan langkah-langkah sebagai berikut:

1. Peneliti membaca novel Bidadari Bermata Bening secara berulangulang hingga memperoleh datadata.

2. Peneliti menggunakan teknik pencatatan yaitu teknik yang digunakan untuk mencatat datadata yang diperoleh dari hasil membaca.

\subsection{Teknik Analisis Data}

Teknik analisis data dalam penelitian ini menggunakan pendekatan moral. Pendekatan moral 
merupakan pendekatan yang melihat sejauh mana karya sastra itu memiliki moral. Pendekatan moral bertolak dari asumsi dasar bahwa salah satu tujuan karya sastra ditengah-tengah masyarakat pembaca adalah berupaya untuk meningkatkan harakat dan martabat manusia sebagai makhluk hidup berbudaya, berpikir, dan berketuhanan. Semi (1993: 71).

Selengkapnya teknik analisis data yang dimaksud, dilakukan dengan tahapan berikut ini.

1. Mengidentifikasi kalimat yang berhubungan dengan moralitas Islam dalam novel Bidadari Bermata Bening karya Habiburrahman El Shirazy.

2. Mengklasifikasikan data, yaitu mengklasifikasikan

(mengelompokkan) data yang menyangkut dengan moralitas Islam yang terkandung dalam novel Bidadari Bermata Bening karya Habiburrahman El Shirazy.

3. Menganalisis/ interpretasi data moralitas Islam dalam novel Bidadari Bermata Bening karya Habiburrahman El Shirazy.

4. Menyimpulkan hasil analisis data.

\section{HASIL PENELITIAN DAN PEMBAHASAN}

Dalam pembahasan ini akan dibahas mengenai moralitas Islam dalam novel Bidadari Bermata Bening karya Habiburrahman El Shirazy. Moralitas dalam Islam biasa disebut akhlak. Maka yang menjadi pembahasan dalam hasil penelitian ini adalah yang pertama akhlak terhadap Allah Swt. yaitu Syukur, Berdoa, Taat beribadah (shalat) dan Ridho. Yang kedua adalah akhlak terhadap Rasulullah yaitu: Mengucapkan shalawat dan Taat pada sunnah Rasulullah. Yang ketiga adalah akhlak terhadap diri sendiri yaitu Sabar, Amanah, Bekerja keras, Rendah hati, Suka menolong dan jujur. Dan yang ke-empat adalah akhlak terhadap masyarakat yaitu: menyayangi anak yatim dan menjenguk orang sakit. Untuk lebih jelasnya dapat dilihat dalam paparan pembahasan dibawah ini.

\subsection{Moralitas Islam dalam novel Bidadari Bermata Bening Karya Habiburrahman El Shirazy}

Pada penenlitian ini penulis mengambil judul penelitian yang berjudul moralitas Islam dalam novel Bidadari Bermata Bening karya Habiburrahman El Shirazy. Dalam bukunya Marzuki dikatakan bahwa khazanah perbendaharaan bahasa Indonesia kata yang setara dengan akhlak adalah moral. Maka peneliti memfokuskan untuk yang menjadi pembahasan dalam penelitian ini adalah macam-macam akhlak yaitu akhlak terhadap Allah Swt., akhlak terhadap Rasulullah, akhlak terhadap diri sendiri dan akhlak terhadap masyarakat.

\subsubsection{Akhlak terhadap Allah Swt.}

Menurut Abudin Nata (2008: 149) akhlak terhadap Allah dapat diartikan sebagai sikap atau perbuatan yang seharusnya dilakukan oleh manusia sebagai makhluk kepada kepada Tuhan sebagai Khalik. Akhlak terhadap Allah Swt. meliputi: syukur, berdoa, beribadah (shalat), dan ridho. Akhlak terhadap Allah Swt. akan dipaparkan pada pembahasan dibawah ini.

\subsubsection{Syukur}

Syukur menurut Kamus Besar Bahasa Indonesia (KBBI) adalah rasa terima kasih kepada Allah. Syukur dapat diartikan sebagai wujud dari rasa 
berterima kasih kepada Allah Swt., atas segala rahmat dan nikmat yang telah Allah berikan dan menjalankan semua perintah-Nya dan menjauhi semua larangan-Nya wujud rasa syukur diungkapkan dengan perkataan, perbuatan, dan hati. Sedangkan lawan dari syukur adalah kufur. Akhlak tentang syukur dapat kita lihat dalam kutipan sebagai berikut.

"Mbak Ningrum menyerahkan kertas itu pada Ayna. Kedua mata Ayna berkaca-kaca membaca isi surat hasil UN miliknya. Zulfa ikut membaca dengan wajah berbinar bangga. Sejurus kemudian Ayna bertakbir dan sujud syukur di lantai dapur itu." (Shirazy, 2017: 13)

Pada kutipan di atas menggambarkan rasa syukur Ayna kepada Allah atas kelulusannya. Tak hanya lulus, Ayna juga mendapat nilai yang sangat membanggakan. Sebagai wujud rasa syukurnya itu, setelah Ayna melihat isi surat hasil UN itu Ayna langsung bertakbir dan sujud syukur di lantai dapur.

\subsubsection{Berdoa}

Menurut Nasution (2009: 54) berdoa adalah satu kebutuhan rohaniah yang diperlukan oleh manusia dalam kehidupan ini, lebih-lebih tatkala ditimpa oleh kesusahan, kesulitan, malapetaka dan lain-lain. Menurut Bastaman (1997: 158) bila seseorang ingin mendapatkan rasa tenang dan tentram maka dekatilah Dia yang Maha-Tenang dan Maha-Tentram agar menghimbas sifat-sifat itu kepada kita. Akhlak terhadap Allah tentang berdoa dapat dilihat dalam kutipan novel sebagai berikut.

"Ayna menyelesaikan shalat witirnya lalu berdoa, meminta keselamatan dunia dan akhirat untuk dirinya, almarhumah ibundanya dan seluruh umat Rasulullah Saw." (Shirazy, 2017: 52)

Kutipan di atas menggambarkan akhlak terhadap Allah yaitu berdoa. Ayna setelah melakukan shalat witir, ia lalu berdoa. Memohon keselamatan dunia dan akhirot untuk dirinya. Serta berdoa untuk almarhumah ibundanya dan seluruh umat Rasululloh.

\subsubsection{Beribadah (Shalat)}

Beribadah yang dimaksud dalam hal ini adalah shalat. Shalat merupakan rukun islam yang kedua. Shalat merupakan bentuk ketaatan manusia dalam beribadah kepada Allah Swt. Allah berfirman dalam Q.S Al-An'am ayat 162 yang artinya: "Sesungguhnya shalatku, ibadahku, hidupku, dan matiku hanyalah untuk Allah Tuhan semesta alam." Akhlak terhadap Allah tentang shalat dapat dilihat dalam kutipan novel sebagai berikut.

"Dik Laila, mohon maaf. Waktu kita sudah habis. Ini sudah jam empat lebih dan kita belum shalat Ashar. Nanti, insya Allah beliau akan menyampaikan jawabannya secara tertulis dan akan kita muat di majalah pesantren. Laila dan para santriwati tampak kecewa dengan kebijakan moderator, yang tak lain adalah Gus Asyiq. Tapi waktu memang tidak mengizinkan, tradisi shalat tepat pada waktunya tidak boleh digeser sedikit pun dan oleh apapun." (Shirazy, 2017: 41)

Pada kutipan di atas menggambarkan bahwa shalat adalah ibadah wajib yang harus dikerjakan tepat pada waktunya. Di pesantren Kanzul Ulum, shalat tepat pada waktunya sudah menjadi tradisi sehingga tidak boleh digeser sedikit pun dan oleh alasan apapun. 


\subsubsection{Ridho}

Ridho adalah bentuk tidak baku dari kata rida. Rida dalam Kamus Besar Bahasa Indonesia (KBBI) adalah rela, suka dan senang hati. Sedangkan menurut bahasa adalah ketetapan hati untuk menerima segala keputusan yang sudah ditetapkan dan ridho merupakan akhir dari semua keinginan dan harapan yang baik. Akhlak terhadap Allah yaitu ridho dapat dilihat dalam kutipan novel sebagai berikut.

"Ummi, Abah, ini Afif mohon pamit. Afif pergi seperti Imam Asy Sybli dulu pergi untuk memperbaiki dirinya. Jangan mencari Afif kalau satu tahun atau dua tahun tidak pulang. Kalau setelah tiga tahun Afif tidak pulang anggap saja Afif meninggal di jalan mencari ilmu. Afif memohon ridho Ummi dan Abah. Tanpa ridho itu, hidup Afif akan sengsara. Maafkan segala salah Afif." (Shirazy, 2017: 210)

Pada kutipan di atas menggambarkan akhlak terhadap Allah yaitu ridho. Afif menulis surat kepada kedua orang tuanya sebagai bentuk pamitan. Ia pamit untuk pergi seperti Imam Asy Sybli dulu pergi untuk memperbaiki dirinya. Ia memohon ridho kepada Ummi dan Abahnya, sebab ridho ridho Allah itu tergantung pada ridho orang tua. Hal ini sesuai dengan sabda Rasul yang artinya: "Ridho Allah tergantung pada ridho orang tua dan murka Allah tergantung pada murka orang tua." (HR. Tirmidzi).

\subsubsection{Akhlak terhadap Rasulullah SAW}

Akhlak terhadap Rasulullah dapat diartikan sebagai suatu sikap yang harus dilakukan oleh manusia kepada Rasulullah sebagai rasa terima kasih atas perjuangannya membawa umat manusia ke jalan yang benar. Akhlak terhadap Rasulullah Saw. meliputi:

\subsubsection{Mengucapkan Shalawat}

Mengucapkan shalawat dan salam kepada Nabi Muhammad SAW, sebagai tanda ucapan terima kasih dan sukses dalam perjaungannya. Secara harfiah, shalawat berasal dari kata ash shalah yang berarti doa, istighfar dan rahmah. Akhlak terhadap Rasul yaitu mengucapkan shalawat dapat dilihat dalam kutipan novel sebagai berikut.

"Ayna mengendarai motornya sambil memperbanyak membaca shalawat. Shalawat adalah doa keselamatan dan kesejahteraan. Siapa mengirim satu shalawat kepada Baginda Nabi, maka Allah akan mengirim sepuluh shalawat kepadanya. Orang itu dalam jaminan keselamatan Allah Swt. Seperti itu Pak Kyai Sobron Ahsan Muslim ,-- suami Bu Nyai Nur Fauziyah, pengasuh utama pesantren di mana ia belajar, -mengajarkan.” (Shirazy, 2017: 6)

Pada kutipan di atas menggambarkan ahklak terhadap Rasul yaitu mengucapkan shalawat. Ayna yang sedang mengendarai motor itu tidak lupa untuk memperbanyak mengucapkan shalawat. Sebab orang yang mengirim satu shalawat kepada Baginda Nabi, maka Allah akan mengirimkan pada orang tersebut sepuluh shalawat serta bagi orang tersebut akan mendapat jaminan keselamatan dari Allah.

\subsubsection{Taat pada Sunnah Rasulullah Saw.}

Kata taat berasal dari bahasa Arab ta'at. Secara bahasa, taat artinya mengikuti atau menuruti, tunduk, dan menerima secara tulus. Adapun secara istilah, taat adalah mengikuti segala perintah dan menjauhi segala larangan.

228 |Jurnal BASTRA (Bahasa dan Sastra), Vol. 4 No. 2, Edisi April 2019/e-ISSN: 2503-3875/ http://ojs.uho.ac.id/index.php/BASTRA 
Taat pada Rasulullah artinya mengikuti segala perintah dan menjauhi segala larangannya. Akhlak pada Rasulullah yaitu taat dapat dilihat dalam kutipan novel sebagai berikut.

"Jangan, Bah. Kalau Abah lakukan itu, Afif akan semakin menderita. Afif tidak mau menjadi penyebab Abah menabrak aturan Baginda Nabi. Seorang muslim tidak boleh melamar di atas lamaran saudaranya. Apalagi merusaknya, membatalkan akad nikah yang sudah siap dilaksanakan. Kita semua sudah tau undangan sudah disebar, Abah. Jangan Abah, jangan. Abah jangan memberi contoh yang tidak baik kepada umat. Jangan Abah, demi Allah, jangan!" (Shirazy, 2017: 183-184)

Pada kutipan di atas, terlihat Afif yang sangat taat akan aturan Nabi. Ketika Abahnya berniat pergi ke Kaliwenang meminta kepada pakde dan bude Ayna agar mereka mau membatalkan pernikahan itu, Gus afif memohon sangat kepada Abahnya untuk tidak melakukan itu. Sebab Gus Afif tau bahwa hal demikian itu adalah menabrak aturan Baginda Nabi. Nabi melarang bahwa seorang muslim tidak boleh melamar di atas lamaran saudara muslimnya, apalagi merusak dan membatalkan akad nikah yang sudah siap dilaksanakan.

\subsubsection{Akhlak terhadap Diri Sendiri}

Akhlak terhadap diri sendiri dapat diartikan sebagai sikap pemenuhan semua urusan kita sepenuhnya kepada-Nya, baik yang menyangkut jasmani maupun rohani. Akhlak terhadap diri sendiri meliputi: sabar, amanah, bekerja keras, rendah hati, suka menolong, dan jujur. Akhlak terhadap diri sendiri akan dipaparkan dalam pembahasan dibawah ini.

\subsubsection{Sabar}

Menurut Kamus Besar Bahasa Indonesia (KBBI) sabar adalah tahan menghadapi cobaan (tidak lekas marah, tidak lekas putus asa, tidak lekas patah hati). Fatah (1995: 101) berpendapat bahwa sabar adalah tindakan yang tidak tergesa-gesa dalam mencapai suatu tujuan, tetapi bukan berarti malas berusaha. Sabar adalah tindakan yang terpuji sedangkan malas adalah tindakan yang tercela. Akhlak terhadap diri sendiri yaitu sabar dapat lihat dalam kutipan novel sebagai berikut.

"Bukan masalah pinter, tapi masalah mental dan habitus keluarga. Jika Ayna lulus Aliyah, lalu lanjut mondok di sini jadi khadimah $\mathrm{Bu}$ Nyai, itu sebuah kemajuan luar biasa. Daripada lulus Aliyah jadi TKW di Arab, kayak Ibunya!" Ayna terhenyak mendengar kalimat yang menusuk itu. Ia menahan emosinya. (Shirazy, 2017: 3)

Pada kutipan di atas menggambarkan sikap sabar yang ditunjukkan oleh Ayna. Neneng adalah salah satu santri yang paling sering usil terhadap Ayna. Neneng selalu menghina Ayna dan ibunya. Mendengar ucapan menusuk yang dilontarkan Neneng untuk dirinya itu tak membuat Ayna tersulut emosi. Ia menahan emosinya.

\subsubsection{Amanah}

Amanah atau kepercayaan adalah menjaga tanggung jawab dan menunaikannya dengan baik menurut semestinya. Bakry (1993: 42) berpendapat bahwa amanah adalah suatu sifat yang menimbulkan saling 
percaya antara masyarakat. Akhlak terhadap diri sendiri yaitu amanah dapat dilihat dalam kutipan novel sebagai berikut.

"Loh, aku kira kamu lihat pertunjukkan wayang kulit sama Ningrum dan yang lain, kok malah mencuci pakaian malam-malam begini. Kenapa nggak besok pagi saja?" Bu Nyai Nur Fauziyah melongok dari pintu kamar mandi yang sedang terbuka.

"Kalau besok pagi kasihan Gus Afifuddin, katanya ini mau dipakai besok ba'da Shubuh. Tadi siang, kulo dititipi Kang Bardi, tapi lupa. Semoga bisa kering." (Shirazy, 2017: 45)

Kutipan di atas menggambarkan sikap amanah yang dilakukan oleh Ayna. Ia dititipi oleh Kang Bardi untuk mencucikan bajunya Gus Afif karena Kang Bardi akan pergi ke Jakarta. Meskipun Ayna lupa, tetapi ia tetap melaksanakan amanah itu dengan sebaik mungkin. Ia tetap mencucikan pakaian Gus Afif. Ia mencucikan baju Gus Afif di malam hari dan berharap dengan bantuan setrika baju tersebut bisa kering di pagi hari.

\subsubsection{Bekerja Keras}

Menurut Mustari (2014: 43) kerja keras adalah perilaku yang menunjukkan upaya sungguh-sungguh dalam mengatasi berbagai hambatan guna menyelesaikan tugas (belajar/ pekerjaan) dengan sebaik-baiknya. Akhlak terhadap diri sendiri yaitu bekerja keras dapat dilihat dalam kutipan novel sebagai berikut.

"Sekarang aku jualan beras di pasar, Mas. Hasilnya aku kumpulkan serupiah demi serupiah. Untuk apa? Aku masih yakin bahwa kita akan kesampaian belajar di Mesir. Aku kumpulkan hasilo jualan beras tiap hari agar ketika tiba saatnya aku harus beli tiket untuk pergi ke Mesir, aku ada uang, Mas. Tapi apa yang kau lakukan? Apa yang kau kerjakan? Kenapa kau tidak bersemangat menatap hidup dan bekerja keras mengumpulkan modal? Mana buktinya kau lelaki yang bertanggung jawab dan bisa dipegang kata-katanya," (Shirazy, 2017: 201)

Berdasarkan kutipan novel di atas, dapat dilihat bahwa Ayna mau bekerja keras dengan berjualan beras di pasar dan hasil dari jualan beras tesebut uangnya akan ia kumpulkan. Ia kumpulkan hasil jualan tersebut serupiah demi serupiah. Agar bila tiba saatnya nanti ketika mereka kesampaian belajar di Mesir, ia ada uang untuk membeli tiket pesawat. Kutipan mengenai bekerja keras ini sesuai dengan firman Allah yang terdapat dalam Q.S At-Taubah ayat 105 yang artinya: "Bekerjalah kamu, maka Allah dan Rasul-Nya serta orang-orang mu'min akan melihat pekerjaanmu itu, dan kamu akan dikembalikan kepada (Allah) yang maha mengetahui akan yang ghaib dan yang nyata, lalu diberitakan-Nya kepada kamu apa yang telah kamu kerjakan."

\subsubsection{Rendah Hati}

Bakry (1993: 78) berpendapat bahwa rendah hati adalah suatu sifat yang menjadikan mukmin bergaul sopan santun, simpatik, tidak sombong, dan tidak merasa lebih dari orang lain. Akhlak rendah hati dalam novel ini dapat dilihat dalam kutipan novel sebagai berikut.

"Saya tidak pernah berpikir jadi terbaik, saya bisa jadi sahabat kalian sudah keberuntungan luar 
biasa. Tidak banyak gadis di desa saya yang bisa sekolah dan belajar di pesantren seperti kita. Yang paling penting adalah ilmu yang manfaat dan barokah." (Shirazy, 2017: 61)

Kutipan di atas menggambarkan Ayna yang memiliki akhlak rendah hati. Saat salah satu temannya ada yang mengatakan bahwa Ayna layak menjadi santri terbaik, Ayna langsung menjawab dengan jawaban merendah bahwa ia tidak pernah berpikir untuk menjadi yang terbaik. Ia bisa menjadi sahabat bagi teman-temannya itu sudah merupakan keberuntungan yang luar biasa baginya. Sebab, tidak banyak gadis di desanya yang bisa sekolah dan belajar di pesantren.

\subsubsection{Suka Menolong}

Menurut Kamus Besar Bahasa Indonesia (KBBI) menolong adalah membantu meringankan beban (penderitaan, kesukaran dan sebagainya). Menurut Mustari (2014: 11) suka menolong adalah sikap dan tindakan yang selalu berupaya membantu orang lain yang membutuhkan. Akhlak terhadap diri sendiri yaitu suka menolong dapat dilihat dalam kutipan novel sebagai berikut.

"Ningrum meraih dompetnya dan mengulurkan selembar uang kertas warna biru pada Ayna sambil tersenyum."

"Begitu ada rezeki aku kembalikan. Insya Allah."

"Santai aja. Aku tinggal ke dapur dulu, yah.” (Shirazy, 2017: 53)

Berdasarkan kutipan novel di atas, terlihat bahwa Ningrum mau menolong Ayna dengan meminjamkan Ayna selembar uang kertas berwarna biru. Ayna meminjam uang tersebut ia gunakan untuk membelikan lego mainan anak-anak. Sebab, ia sudah berjanji untuk membelikan Gus Naufal mainan jika ia mau belajar. Akhlak yang ditunjukkan oleh tokoh Ningrum ini sesuai dengan firman Allah yang tertera dalam Q.S Al-Maidah ayat 2 yang artinya: "Dan tolong menolonglah kamu dalam (mengerjakan) kebajikan dan takwa, dan jangan tolong menolong dalam berbuat dosa dan pelanggaran. Dan bertakwalah kamu kepada Allah, sesungguhnya Allah amat berat siksaNya."

\subsubsection{Jujur}

Menurut Mustari (2014: 11) jujur adalah suatu perilaku yang didasarkan pada upaya menjadikan dirinya sebagai orang yang selalu bisa dipercaya dalam perkataan, tindakan, dan pekerjaan baik terhadap dirinya ataupun pihak lain. Jujur adalah suatu sikap seseorang yang biasanya diungkapkan dengan ucapan ataupun perbuatan dengan spontan sesuai dengan keadaan yang sebenarnya tanpa ada rekayasa dari yang diucapkannya dan dilakukannya. Akhlak jujur dalam novel ini dapat dilihat dalam kutipan novel sebagai berikut.

"Jujur, sebenarnya Ummi merasa eman-eman kalau kau Cuma jadi khadimah disini. Apa kata masyarakat, santri dengan nilai UN tertinggi se-Jawa Tengah kok putus kuliah? Pesantren ini juga malu rasanya. Tapi yah tidak apa, kalau kau merasa nyaman tetap ngaji di sini, kau boleh tetap membantu Ummi." (Shirazy, 2017: 79)

Pada kutipan di atas dapat dilihat Bu Nyai Nur Fauziyah yang berkata jujur kepada Ayna. Bu Nyai menginginkan Ayna untuk menerima tawaran kuliah bebas test dari rektor 
UNY. Bu Nyai mengungkapkan kejujurannya bahwasanya eman-eman kalau peraih nilai UN tertinggi se-Jawa Tengah seperti Ayna harus putus kuliah. Sebab, pesantren juga akan malu rasanya.

\subsubsection{Akhlak terhadap Masyarakat}

Akhlak terhadap masyarakat adalah sifat yang tertanam dalam jiwa manusia yang dilakukan secara spontan tanpa pertimbangan terlebih dahulu dalam lingkungan atau kehidupan. Akhlak terhadap masyarakat meliputi:

\subsubsection{Menyayangi Anak Yatim}

Salah satu akhlak terhadap masyarakat adalah menyayangi anak yatim. Anak yatim mendapat perhatian yang besar dari Islam. Islam sangat menganjurkan untuk berbuat baik kepada anak yatim dan melarang keras untuk berbuat zhalim kepada mereka. Akhlak tentang menyayangi anak yatim dapat dilihat dalam kutipan novel sebagai berikut.

"Sudah setengah tahun, Ayna membina anaka-anak itu. Dengan kemampuan yang ia punya, ia ajar mereka pelajaran sekolah. Ia usahakan mereka untuk tetap mendapatkan pendidikan yang layak dengan cara homeschooling, atau sekolah di rumah." (Shirazy, 2017: 232)

Pada kutipan di atas menggambarkan akhlak menyayangi anak yatim. Sudah setengah tahun Ayna membina anak-anak yatim itu. Ia mengajarkan anak-anak itu pelajaran sekolah sesuai dengan kemampuan yang ia bisa. Ayna mengusahakan agar anak-anak itu mendapatkan pendidikan yang layak dengan cara sekolah di rumah.

\subsubsection{Mengunjungi Orang Sakit}

Menjenguk orang sakit merupakan akhlak yang harus kita lakukan dalam bermasyarakat. Ada pahala yang besar yang kan kita dapatkan ketika kita mau menjenguk orang yang sakit. Rasulullah bersabda yang artinya, "Barang siapa yang menjenguk orang yang sakit, maka ia akan selalu berada dalam kebun surga". Orang-orang bertanya, "Wahai Rasulullah, apa yang dimaksud dengan kebun surga itu?" Rasulullah menjawab, " Buahbuahnya." (HR. Muslim)

"Malam itu juga ia nekad mengendarai mobil menuju Magelang. Ia ingin segera sampai rumah sakit tempat Gus Afif dibaringkan. Sepanjang perjalanan air matanya terus mengalir tak bisa ia tahan. Selama ini ia menderita tapi ternyata Gus Afif lebih menderita darinya. Seandainya Gus Afif ditakdirkan meninggal, ia ingin menjadi orang yang pernah menalqinnya dengan kalimat tayyibah diujung nafasnya." (Shirazy, 2017:198)

Pada kutipan novel di atas terlihat Saat Ayna mendapat info dari mbak Ningrum lewat sambungan telepon yang mengabarkan bahwa Gus Afif sedang mengalami koma, Ayna malam itu juga langsung bergegas ke Magelang. Ia ingin segera sampai menuju rumah sakit tempat Gus Afif dibaringkan. Ia datang untuk menjenguk pemuda yang sangat ia cintai itu.

\section{PENUTUP}

\subsection{Kesimpulan}

Berdasarkan pembahasan hasil penelitian, dapat disimpulkan bahwa moralitas Islam dalam artian yaitu akhlak yang terdapat dalam novel 
Bidadari Bermata Bening karya Habiburrahman El Shirazy mencakup empat akhlak, yaitu yang pertama akhlak terhadap Allah Swt. yaitu Syukur, Berdoa, Taat beribadah (shalat) dan Ridho. Yang kedua adalah akhlak terhadap Rasulullah yaitu: Mengucapkan shalawat dan Taat pada Rasulullah. Yang ketiga adalah akhlak terhadap diri sendiri yaitu Sabar, Amanah, Bekerja keras, Rendah hati, Suka menolong dan jujur. Dan yang ke-empat adalah akhlak terhadap masyarakat yaitu: menyayangi anak yatim dan menjenguk orang sakit.

\subsection{Saran}

Berdasarkan hasil penelitian, yang menjadi saran penelitian ini adalah:

1. Agar penelitian mengenai moralitas Islam di dalam karya sastra harus lebih ditekankan kepada siswa, selain sebagai pembelajaran juga sebagai pedoman hidup.

2. Agar pembaca dapat memberikan masukan terhadap hasil penelitian ini.

3. Bagi guru, agar bisa memberikan pembelajaran yang berkaitan dengan moralitas Islam dalam suatu karya sastra termasuk novel. Hal ini perlu dilaksanakan agar siswa dapat melihat bahwa suatu karya sastra dapat dijadikan pembelajaran yang begitu menyenangkan dan dapat pula diaplikasikan dalam kehidupan sehari-hari.

4. Semua nilai yang terkandung dalam novel Bidadari Bermata Bening karya Habiburrahman El Shirazy dapat dijadikan referensi penelitian bagi peneliti lainnya dalam melakukan penelitian selanjutnya.

\section{DAFTAR PUSTAKA}

Adi, Ida Rochani. 2011. Fiksi Populer: Teori dan Metode Kajian. Yogyakarta:

Pustaka Pelajar.

Al-Ghazali, Imam. 2005. Ihya 'Ulumuddin (terjemahan). Bandung: Pustaka.

Al-quran dan terjemahannya. 2018. Departemen Agama RI. Jakarta Timur: CV Darus Sunah.

Aminuddin. 2002. Pendidikan Agama Islam untuk Perguruan Tinggi Umum. Jakarta: Ghalia Indonesia.

Azra, Azyumardi. 2005. Ensiklopedi Islam. Jakarta: Pt Ichtiar Van Hoeve.

Bastaman, Hanna Djumhana. 1995. Integrasi Psikologi dengan Islam Menuju Psikologi Islami. Yogyakarta: Pustaka Pelajar.

Bertens, K. 2002. Etika. Jakarta: Gramedia.

Durkheim, Emile. 1990. Pendidikan Moral Suatu Studi Teori dan Aplikasi Sosiologi Pendidikan. Jakarta : Erlangga.

Ikhlas, Hadiah. 2002. Kamus Besar Bahasa Indonesia. Jakarta: Balai Pustaka.

Jabrohim. 2014. Teori Penelitian Sastra. Yogyakarta: Pustaka Pelajar.

Kosasih, E. 2012. Dasar-dasar Keterampilan Bersastra. Bandung: Yrama Widya.

M, Amril. 2007. Akhlak Tasawuf. Pekanbaru: Program Pasca Sarjana UIN Suska Riau dan Lsfk2p.

Masyhur, Kahar. 1987. Membina Moral dan Akhlak. Jakarta: Kalam mulia. 
Mustari, Mohamad. 2014. Nilai Karakter Refleksi untuk Pendidikan. Jakarta: PT Raja Grafndo Persada.

Nasution, M. Yunan. 2009. Pegangan Hidup. Solo: Romadhani.

Padi, Editorial. 2013. Kumpulan Super Lengkap Sastra Indonesia. Jakarta: CV Ilmu Padi Infra Pustaka Makmur.

Redaksi, PM. 2012. Sastra Indonesia Paling Lengkap. Depok. Pustaka Makmur.

Semi, M. Atar. 1993. Metode Penelitian Sastra. Bandung: Angkasa.

Shirazy, Habiburrahman El. 2017. Bidadari Bermata Bening. Jakarta:

Republika Penerbit.

Sutana, Dwi. 2015. Karya Sastra dalam Harian Haluan Kepri. Tanjung Pinang Barat: Kantor Bahasa Kepulauan Riau.

Tarigan, Henry Guntur. 1995. Dasardasar Psikosastra. Bandung. Angkasa.

Wellek, Rene dan Warren Austin. 2016: Teori Kesusastraan. Jakarta. Gramedia IKAPI.

Wicaksono, Andri. 2014. Pengkajian Prosa Fiksi. Yogyakarta: Garudhawaca.

Yuwono, Untung. 2007. Gerbang Sastra Indonesia Klasik. Jakarta. Wedatama

Widya Sastra. 